\title{
Coulisses
}

Revue de théâtre

2 | Automne 1990

Spécial Festival des idées : Besançon ville ouverte aux jeunes

\section{Contes du Congo}

par Alfred M’Bongo musicien chanteur

\section{Rédaction}

\section{CpenEdition}

Journals

Édition électronique

URL : http://journals.openedition.org/coulisses/1595

DOI : $10.4000 /$ coulisses. 1595

ISSN : 2546-9460

\section{Éditeur}

Presses universitaires de Franche-Comté

Édition imprimée

Date de publication : 1 novembre 1990

Pagination : np

ISSN : 1150-594X

Référence électronique

Rédaction, "Contes du Congo », Coulisses [En ligne], 2 | Automne 1990, mis en ligne le 04 juillet 2017, consulté le 22 octobre 2019. URL : http://journals.openedition.org/coulisses/1595; DOI : 10.4000/

coulisses. 1595

Ce document a été généré automatiquement le 22 octobre 2019

Coulisses 


\section{Contes du Congo}

par Alfred M’Bongo musicien chanteur

\section{Rédaction}

1 La salle, ce jour-là, est quasi pleine d'un public de tous âges, enfants et adultes. Le spectacle débute en chansons, et est ponctué d'intermèdes musicaux

2 Le prologue suscite un certain étonnement chez les plus jeunes. Aussi, lorsque débute la narration, il faut un certain temps pour que l'intérêt des enfants se reporte sur le conteur ce qui se répercute sur son jeu. Peu à peu, il prend de l'assurance, s'appuyant sur un jeu plus théâtral que celle du trésor du figuier : il imite les voix des différents personnages, leurs gestes, leurs déplacements, d'une façon stylisée, et y ajoute des bruitages.

3 Le conte ne prend vraiment forme qu'à partir de l'intervention d'un enfant. Alors qu'Alfred M’Bongo annonce l'arrivée d'un dragon, l'enfant lance : «ça n'existe pas, les dragons!»

4 Le conteur s'arrête, regarde l'enfant et répond: "c'est ce qu'on va voir. " Alors le combat du jeune héros, le petit Dan, contre le dragon, prend vie au cours du dialogue entre le conteur et l'enfant.

5 Quoique ce dernier manque d'une certaine spontanéité, qu'il semble parler surtout pour être remarqué, le conteur tire parti de cette difficulté; son jeu devient plus convaincant - et plus convaincu -, encouragé par les rires et les réactions diverses que le « duel » éveille.

6 Pourtant, on ne parvient jamais à une entente complice entre conteur et spectateurs. Les enfants s'agitent, parlent, jouent avec les coussins, et offrent en définitive un spectacle qui concurrence celui de la scène et lui nuit. 
